D MARSHA ORGERON

\title{
LIBERATING IMAGES?
}

\section{Samuel Fuller's Film of Falkenau Concentration Camp}

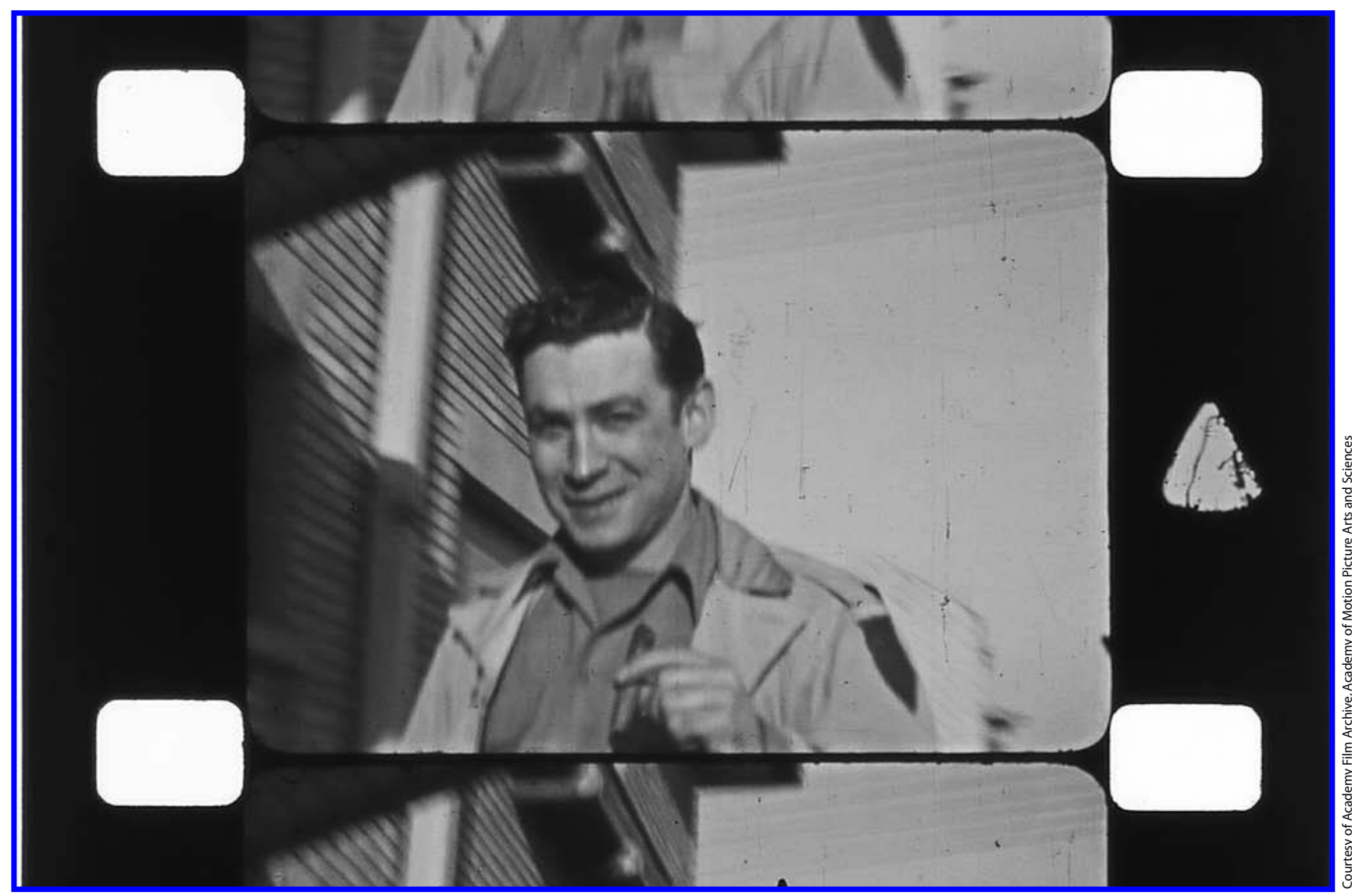

A glimpse of Samuel Fuller on one of the $16 \mathrm{~mm}$ reels he shot during WWII

8-point Goudy, Widescreen Pica gauge, Moviola-reporter and film director spill blood on the same emotional battlefield of what is fit to print, and what is fit to film. 
ON 9 MAY 1945, THE DAY after V.E. Day, future maverick Hollywood director Samuel Fuller shot a twentytwo-minute film recording the aftermath of the liberation of Falkenau, a Nazi Concentration camp in Czechoslovakia. ${ }^{2}$ He used a $16 \mathrm{~mm}$ Bell \& Howell camera that his mother sent him while he was overseas during World War II as a soldier in the 1st United States Infantry Division, colloquially known as the "Big Red One."' In his posthumously published autobiography, $A$ Third Face (2002), Fuller explains that he was asked by his battalion commander, Captain Kimble R. Richmond, to "film the gruesome spectacle" of burial preparations for the camp victims' emaciated bodies, which had been "thrown on top of each other like newspapers" (217). Also present were the near-dead who "raised their bald heads and looked at us, eyes sunken in anguish, their mouths agape, a hand here and there reaching out, grasping for anything, begging us for assistance in helpless silence" (214). Fuller's newspaper metaphor invokes his journalistic background and acknowledges that the corpses represented unseen and untold stories. In the wake of the Nazi violation of decency and humanity, what was fit to print-or to film for that matter-was in the process of being revised.

Fuller's Falkenau film contains images that would haunt the filmmaker throughout his life and career, emerging most obviously in the film that revisits Fuller's war experiences, The Big Red One (1980). It is not, however, only Fuller's semi-autobiographical film that deals with the witnessing of traumatic incidents. Many of Fuller's movies are about characters who see or experience something painful, damaging, terrifying, or incomprehensible, which they struggle with and often fail to make sense of. Fuller's fascination with bearing witness is evident in the journalistic career that preceded his military service as well as in the amateur footage he shot during the war. Fuller, in fact, framed his decision to enlist in terms of his interest in being a documentarian: "I had a helluva opportunity to cover the biggest crime story of the century," Fuller wrote, "and nothing was going to stop me from being an eyewitness" (105). Fuller's film of Falkenau, however, suggests that what the nascent director found was more than just an opportunity to see things for himself.

Like other liberation footage, Fuller's film does not capture the full horror of the concentration camps. Such films, as Nicolas Losson has demonstrated, can necessarily record only the aftermath of atrocity, a particular moment in the lifeline of the camp. ${ }^{4}$ The film focuses on the burial ritual for the camp's victims as well as on the "respected townspeople" (215) of Falkenau, who were compelled by Captain Richmond to "appear at the gates of the camp the next morning or face a firing squad" (216) to watch the proceedings along with the liberating division, the camp's survivors, and Fuller's camera. The townspeople were obliged to act as witnesses-a measure taken to ensure that those who professed ignorance of what had happened inside the camp would see the evidence of Nazi brutality for themselves - and as participants who helped "prepare the camp's victims for a decent funeral" (217). These individuals were, in other words, watching the victims of the Nazi camp and each other; but they were also on display, performing, all in the context of this ritualistic attempt at restoring posthumous dignity to the camps' victims.

This scenario of participation and witnessing is repeatedly played out, albeit in different guises, in other films of camp liberations and in newsreels that made their way to theaters worldwide in the spring of 1945. In Frontline: Memory of the Camps (1985), the PBS broadcast name given to a never-completed 1945 documentary with footage shot by British and American cameramen, SS guards are shown digging graves and handling bodies, and local townspeople are brought in to watch the proceedings and to study the proof of camp abuses, all evidencing the prevailing philosophy articulated by the film's narrator: "It had to be seen to be believed."' Jeffrey Shandler notes the importance of witnessing as a theme in the liberation newsreels:

[T]wo kinds of images predominate in the newsreels: In addition to shots of the camps' former inmates, both the living and the dead, are scenes that document local Germans being forced to witness the camps' conditions and the fate of their victims. The latter include footage of Allied soldiers compelling German civilians and military prisoners to behold piles of corpses ... There are also scenes of Germans' compulsory participation in burying or reburying the dead ... ${ }^{6}$

Fuller's film of Falkenau, then, is one of many such documents that fit into the genre of liberation footage. It is also, however, an unusual film in terms of its careful, formalistic orchestration.

Despite a significant body of critical work about Fuller and especially about his interest in the subject of war, this amateur footage has received only occasional, passing acknowledgment. ${ }^{7}$ What follows here is an attempt to remedy this gap. As Janet Walker notes, "we have an ethical and political obligation to remember, acknowledge constantly, and deal with the aftermath of traumatic events" while also realizing that "these events are subject to interpretation as they are experienced, reimagined, reported, written down, and visually com- 
municated."' ${ }^{\prime}$ Fuller's record of trauma-that of the camp's victims, the camp's survivors, the camp's neighbors, as well as his and the other liberating soldiers'functions simultaneously as documentation and interpretation. His experience of witnessing, filming, remembering, and also revising his memory of this event enriches our understanding of World War II and Holocaust representation. Because it is an immensely personal document, the film also functions as a valuable artifact of one of the director's formative war experiences, one that would, as he put it in reference to another traumatic act of witnessing (seeing the severed head of another soldier), remain "imprinted on my mind like a leaf in a fossil, never to fade away" (114).

The need for witnessing and recording was a matter of policy during the final Allied sweep through Nazi territory at the conclusion of the European segment of the war. Following a high-profile visit on 12 April 1945 from Generals Dwight Eisenhower, George Patton, and Omar Bradley to the first American liberated Nazi Camp-Ohrdruf (a Buchenwald subcamp) — the call to document Nazi atrocities went out to journalists and members of Congress. Evidence was needed for future war-crimes trials, but it was equally understood that a documentary archive of proof was imperative for the education of Germans and the rest of the world about the human destruction wrought by National Socialism. Consequently the military-both officially through the Army Signal Corps and, in the case of Fuller and other amateur cinematographers among enlisted ranks, somewhat more informally-began to shoot footage that evidenced Nazi barbarism. ${ }^{9}$

As Shandler makes clear, Eisenhower "was at the forefront of establishing the act of witnessing the conditions of recently liberated camps as a morally transformative experience." 10 The narrative which unfurls in Fuller's footage is precisely one of painstaking witnessbearing to the denouement of the war, to the reasons for fighting it laid out in unsparing detail, and to the edifying, if equally punitive, act of bystanders (in every sense of the word) being forced to confront the reality of what had been done. Fuller realized the importance of showing these living, witnessing subjects, writing that his "twenty minutes of $16-\mathrm{mm}$ film had recorded the sober reckoning of those civilians" (217). The idea of a "sober reckoning" makes it clear that Fuller had a certain degree of faith in the potentially humanizing and perhaps even redemptive consequences of seeing firsthand the evidence of Nazi abuses. Shandler observes a related moral imperative in viewing the graphic newsreel footage of camp liberations, which "codifies the act of witnessing for American audiences as un- pleasant, shocking, repulsive, yet arousing, compelling, necessary, and ultimately redemptive."11

Discussing The Big Red One (1980)—which represents, as he puts it, "fictional life based on factual death"12_-Fuller explains that writing the novel and making the film was "how I ultimately came to grips with my experiences" (122). I want to consider this statement in the context of Fuller's film of Falkenau, which Fuller claims he put away upon his return to the United States in the fall of 1945 and never took out again because "it would be too painful to watch, bringing back all the horrors of the war years" (217). ${ }^{13}$ This statement is fascinatingly misleading. Fuller in fact edited the Falkenau footage onto a larger reel with his other war footage, presumably when he returned to the United States, so he would have seen the film both to edit it and again if he was ever to look at the other footage (which he did). He also revisited the Falkenau footage in detail for the making of a documentary, Falkenau: The Impossible (Emil Weiss, 1988), which revolves around his filming of the newly liberated camp. ${ }^{14}$ Finally, he consistently revisited "the horrors of the war years" in print, interviews, and film throughout his career.

Fuller's misleading statement speaks to the fraught emotional politics of his filming and then possessing, both in a material and psychological sense, this footage throughout his life. Like Margaret Bourke-White, who photographed camp liberations, Fuller's relationship to the moment of his filming may have created a kind of dissociating effect. As Bourke-White explains it: "Using the camera was almost a relief. It interposed a slight barrier between myself and the horror in front of me ... The protective veil was so tightly drawn that I hardly knew what I had taken until I saw prints of my photographs." 15 Bourke-White's delayed reaction to what she-or rather as she understands it, her camera-had witnessed, resonates with Fuller's own experience, which left him "numb” (217). In the Weiss documentary, Fuller in fact describes the act of filming these events as an "advantage": "I was kept busy doing all this, what you're seeing, and others just had to watch." The camera, then, mediates the horrific nature of that experience while the moral imperative of a greater duty to document aids in the rationalization of the act of filming.

Fuller's heavily edited Falkenau film is, roughly speaking, divided into three parts-depicting first the preparation of the dead for burial, second the transportation of the bodies to the burial site, and finally the burial itself. ${ }^{16}$ The film begins with raised white titling photographed on darker backgrounds and edited onto the film, likely after Fuller returned stateside: "V-E+1 
May 9, 1945 / Produced in Falkenau Concentration Camp / Czechoslovakia." With images of a swastika, a gun, and the Big Red One alongside some of the titles, the opening credits attribute the presentation of the film to the 16th Infantry Regiment of the 1st U.S. Infantry Division, supervision to Captain Kimball Richmond, and photography to Fuller. ${ }^{17}$

The first time Fuller captures evidence of the abject fate of those interned in the camp follows a shot of the front of a jeep with its own version of titling painted under the front windshield, a message with both selfcongratulatory and, given what follows it, ironic resonances: "Good Show!" Up until this moment Fuller's camera has been largely stationary, but here the camera pans from the jeep, with a smiling G.I. blurrily visible behind the wheel, to a group of men walking with shovels. Fuller's treatment of these men reflects the significance of who they are: the "leading citizens of Falkenau," who were "handpicked by Richmond because they said they didn't know anything about a camp near the village, right on the outskirts." 18 These are the men putting on the "good show" that follows and Fuller seems cognizant of this performative aspect of the film, explaining in the Weiss documentary that: "The story you are about to see was written by him [Captain Richmond], but really it wrote itself."

Although history has provided the mise-en-scène for what follows, Richmond is clearly orchestratingone might follow Fuller's lead and say directing-this film, which places on display both the camp's victims and the "leading citizens of Falkenau" who are quite literally made responsible-by Richmond and by the camera-for what follows. As Losson has illustrated, most liberation films were "shot in extreme confusion," from which we may infer that "these images correspond not so much to a conscious and planned operation, but
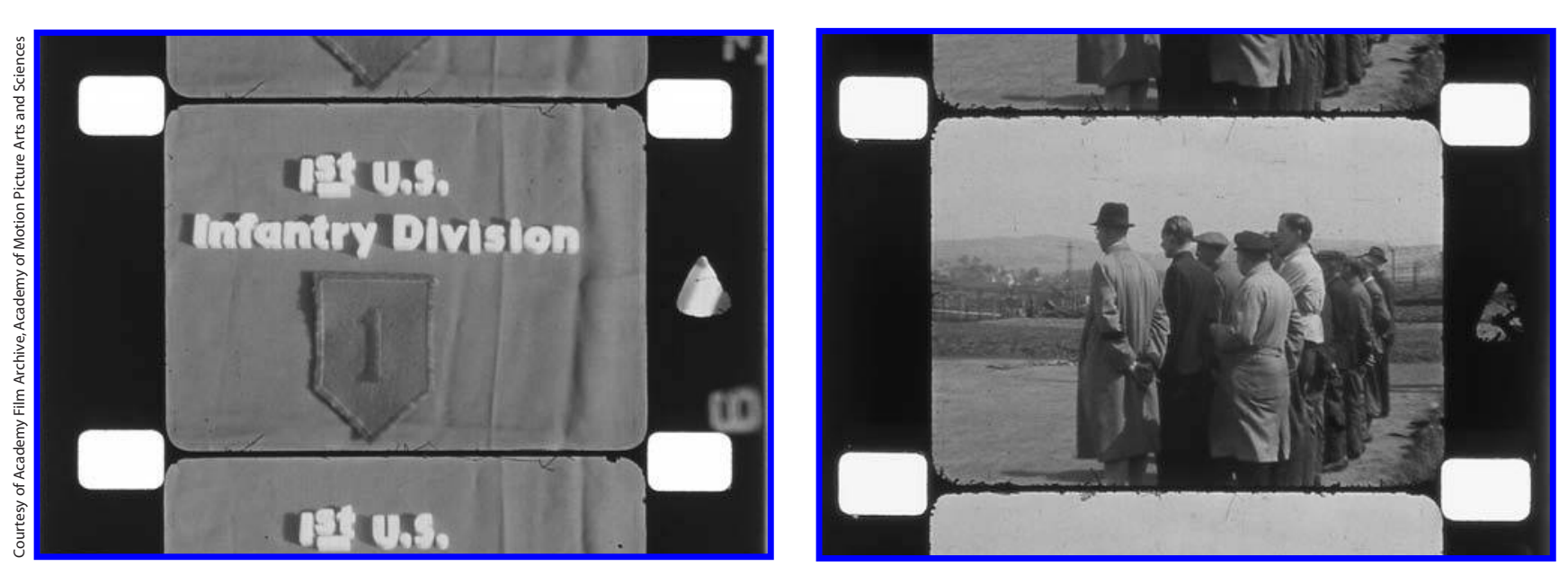

rather to a simple attempt to capture the phenomenon in its opacity." ${ }^{19}$ Fuller's film does not reflect this sense of confusion; rather, it presents an unusually orderly narrative, an attempt to ritualize and rationalize the "extreme confusion" typical of the experience of liberating. This marked difference from other liberation footage recalls Vivian Sobchack's taxonomy of the various ways - accidental, helpless, endangered, interventional, ethical, or professional - in which death can be photographically documented. ${ }^{20}$ Although the ethical weight of his observational role is shifted by virtue of the fact that Fuller's film is largely a post-mortem, of sorts, his cinematography and editing still inscribe the film with a highly subjective orientation in which his moral stance may be detected. He is, in Sobchack's terms, "the immediate viewer-the filmmaker with camera" who "physically mediates his or her own confrontation with death ... and charges it with a moral meaning visible to others." ${ }^{21}$ The carefulness of his cinematography and editing suggest a desire to bring order to his subject. It also reflects a desire to carefully scrutinize and assign blame to this group of diegetic spectators.

In the film, these "leading citizens of Falkenau"who reappear throughout the film-walk, stop, and are then pictured grouped together looking off at something the camera does not reveal. The men appear to be silent and are relatively expressionless as they gaze screen left. Abruptly the footage cuts to what are implied reverse shots depicting the subject of the men's gazes: two quick takes-one second and two seconds respectively-of a small room with naked corpses and blankets stacked on top of each other in precisely the manner described by Fuller in A Third Face.

Fuller's first presentation of human evidence of Nazi atrocities thus occurs in the form of a kind of blink. The language of the film suggests that these men

Divisional credit and the "leading citizens of Falkenau" 
stare at what the camera only provides a glimpse of. However, it is worth remembering the degree to which Fuller was mediating the unfolding narrative both at the moment of filming and in "postproduction." The film is not a replica of Fuller's, or even of these men's experience; it is an ordered version of that experience. It is not just recording, but crafted narration. This is even more the case because careful study of the footage and of the geography of the camp reveals that this is truly an impossible reverse shot: these men are looking away from the structure that contains the bodies (it is actually behind them) and therefore Fuller has made an editorial intervention that suggests they are looking at something at that particular moment that they simply could not be seeing.

This is not a matter of deception; Fuller took expressive license in the editing of this sequence to introduce the horrific nature of the film's subject in a fashion that links the sight of the corpses to the men having to face up to their deaths. This is an early assignation of responsibility that sets the moral framework for what will follow, in some ways justifying the act of filming the unfilmable by attributing the gaze to someone other than the cinematographer himself. The hurried nature of the "reverse shots" suggest the degree to which, as Sobchack understands it, "vision must visibly respond to the fact that it has broken a visual taboo and looked at death," here by temporally easing into that sight and by affixing this gaze to those implicitly guilty for its occurrence. ${ }^{22}$ Since there is no telling how Fuller conceived of the future life of this film, it is worth wondering if his formal practices here enact a drama of deciding what was "fit to film" both on the spot and in the editing room. Do these first shots of the camp victims formally reflect shock, horror, shame, guilt, or perhaps simply an attempt to treat the dead with dignity? These are speculative notions, but what is certain is that these "blinks" do not set a formal pattern for what is to come; rather they offer an introduction to the real subject of the entire film: the fate of those discarded bodies.

Given the appalling nature of Fuller's subject matter it is interesting that what follows these shots is not any immediate action taken in dealing with the corpses, but rather a relatively long take depicting the observational process. Connected to this first traumatic revelation by a brief shot of two American soldiers, the heroic and moral centers of the operation and of Fuller's film, the camera begins a long pan left-but in terms of motion rather quick, too quick to really discern facial expressions or attire with any accuracy-across another group of men crouched on a slight hillside, overlooking the events transpiring below. ${ }^{23}$ In Weiss's documentary, made more than forty years after these events took place, Fuller, while looking at this same footage, identifies these men as "the prisoners watching the show," using the language of performance in a fashion perhaps curious given that the usual "privileged" spectators in liberation films are the German people brought in from the local towns. Elsewhere Fuller claims that it was "German officers loading the bodies of their victims onto wagons, pulling them through the town" and that the townspeople had "to look at what they claimed they didn't know anything about. The camps, the ovens, the dead," suggesting that these townspeople, then, would likely constitute the group of witnesses on the hillside. ${ }^{24}$ In A Third Face, Fuller states that "POWs, mostly teenage Hitlerjugend, helped place the shrouded corpses in a mass grave" (217). Here he distinguishes these POWs from "the townspeople" who also participate in and observe the ritual. Prior to learning of Fuller's identification of the men on the hillside as liberated prisoners in Weiss's documentary, I felt certain that they were local townspeople, which would follow the conventions of other liberation films. SS guards - usually male, but sometimes female - or German civilians were typically forced to handle the bodies following camp liberations and local townspeople were brought in to watch this process or to tour the camps and see the ex-prisoners, both living and dead, for themselves.

Fuller sometimes contradicts himself in interviews regarding this period, which is not at all surprising. I do not think that Fuller intentionally confuses the events of this day, but both the passage of time and the disturbing nature of these events conspire to complicate the accuracy of memory to produce a version of what Janet Walker terms "disremembering" or awkward remembering. ${ }^{25}$ It is certainly possible, even likely, that German prisoners and local townspeople participated in various aspects of this event and that the hillside was predominantly or exclusively populated with prisoners, although they also appear on the "main stage" in various shots. However, the most striking issue that this confusion over the hillside witness and participant identification raises is not who really crouches atop that hill or who is handling the bodies, or even how Fuller remembered or later chose to narrate these events; rather, it is one of spectatorship and interpretation. This ambiguity suggests the complexity of what might otherwise seem like a readily legible cinematic document: if these men are survivors, I would not read their spectatorship in the same way as I would if they are local townspeople or SS prisoners. As Shandler points out, there is a rather rigid, perhaps even simplistic moral framework for interpreting this kind of footage 
in which meaning is predetermined by identity-liberators are heroic, victims tragic, perpetrators and bystanders guilty; but this requires attention beyond what I am able to provide here. Cornelia Brink's observation about the naïve assumption that seeing photographs of camp liberations is somehow equivalent to "understanding what they represent" is applicable to the simultaneous legibility and opacity of such an intimate documentation as Fuller's film provides, as it is to any liberating cinematographer's footage. ${ }^{26}$

What we are left with is intent: Richmond's choreography of the scenes that follow and Fuller's representation of them purport to figure the survivors as a counterpoint to the corpses being handled by the local citizenry/German prisoners (it may be a combination of both), who are assigned guilt both as spectators and as recruited (forced?) participants in this ritual. But Fuller's film also makes a statement about the multivalent power of witnessing, both here and elsewhere, suggesting the different ways of seeing the same events: as evidence (from the photographic perspective), as guilt (from the civilian or SS perspective), as moral righteousness (from the liberating perspective), and as something less clear, but perhaps bordering on triumph, however futile or relative (from the surviving prisoners' perspective). These significations are in some ways built into the framework through which we view these supposedly liberating images, but they are equally subject to change based upon our understanding of who is doing what and for what reason.

Carol Zemel understands photographs of similar forced German witnessing in a fashion that is relevant to Fuller's film, which also "constructs positions of witness, perpetrator, and heroic liberator. But the pictures of civilians also enact a double witnessing: the real spectacle is not the dead, but German citizens photo- graphically designated guilty bystanders to Holocaust atrocity." ${ }^{27}$ Although I disagree with Zemel's account of what "the real spectacle" is-especially in Fuller's case, because the dead are so clearly central to the visual schema of the film and to the ideological project in which it is participating - her point about the assignation of guilt and the spectacle of witnessing is confirmed by Fuller's insistence on filming the liberated prisoners and the guilty "performers" in a fashion that connects them to the town just outside the gates of the camp as well as to the dead within it. In some ways, too, the spectacle on display is the Allied victory itself, here played out in careful acts of compassion and discipline.

The subsequent shot shows a group of men from the neighboring town (to avoid unnecessarily complicating the remainder of my discussion, I will now follow Fuller's identification, in Weiss's documentary, of participants) getting white undergarments out of a wagon and walking towards the camera. A cut takes us to the focus of their attention: an emaciated man on a stretcher. Fuller initially and repeatedly cuts away from the corpse (we soon realize there is no chance this man is alive) as he is dressed by two men being instructed by an American soldier. But Fuller then reframes the shot, coming closer and closer as he changes positions around the body. This scene is repeated, with another corpse being brought out of the building - Fuller termed it a "putrid hut" (217) — and the camera panning up to witness the hillside observers standing all at once in what was presumably a gesture of respect for the dead, choreographed or not. Fuller is unsparing in what he now films: naked, skeletal, and often visibly diseased bodies being clothed, intercut with shots of the standing observers. The film and its maker signify clearly: this is what I am seeing and this is also what they-both the observers and the participants—are seeing.

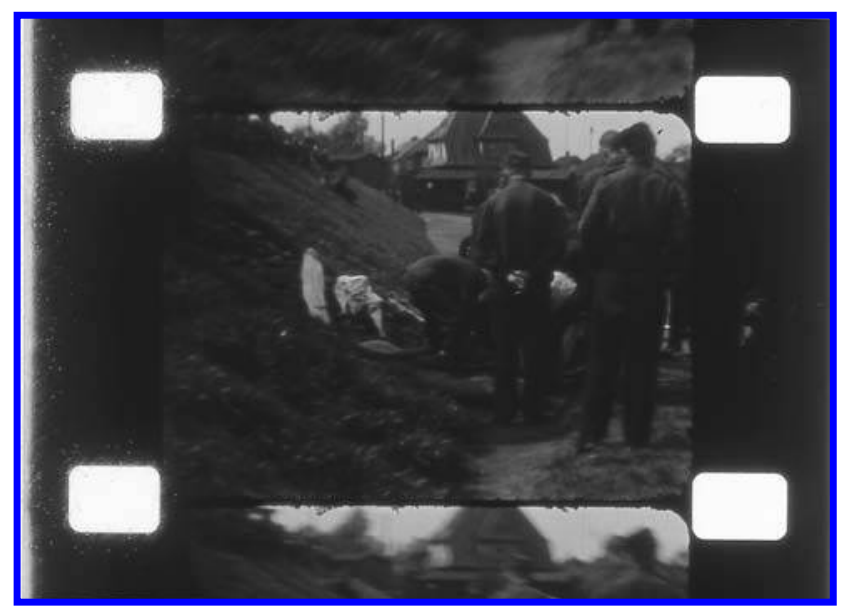

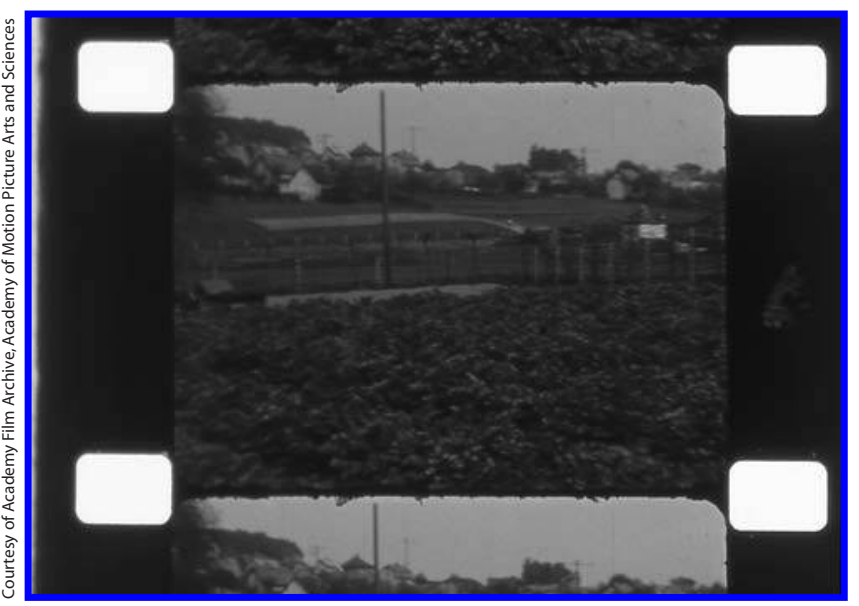

The first image in the panoramic shot that ends (right) with a corpse being dressed 
Fuller continues to film the relatively gentle preparation of the bodies, revealing the manifestationssores, swelling, emaciation, makeshift bandages — of the conditions in which these human beings had been kept. The bodies, now dressed in dark pants and jackets, are laid out on (mostly) white sheets in a row and Fuller pans right to connect this growing row of the deceased to the observers on the hillside, affirming their proximity and status as witnesses to this attempt at dignifying the dead.

These shots also repeatedly reveal the proximity of the neighboring town in the background of the camp, a closeness that Fuller later emphasizes in an uncut panoramic shot of the camp's wire boundary fence with the town in isolation just outside of it. The shot makes a similar point as the one just discussed: here is where the free lived their lives and they were-vehement denials aside-surely aware of what was happening in their backyards. ${ }^{28}$ Fuller's pan extends all the way around the camp's borders from the outlying town to an open expanse, to the observers situated on the hillside, all with the camp's wire fence as a continuous point of reference. This nearly 360-degree unedited take eloquently argues against the mass denial of awareness frequently encountered by liberating soldiers and it ends with Fuller walking the camera (in an approximation of a dolly shot) in towards one of the naked corpses. Beginning with the town and ending with a corpse, Fuller's formally sophisticated shot silently but forcefully assigns culpability.

But it also achieves something else: Fuller's panning movement and walking-in reminds us of the cinematographer's guiding hand, his presence as witness and, in some ways, as judge. The climax of this portion of the film repeats this articulation of Fuller's dual role: it is marked by a pan left across the completed row of dressed bodies on white sheets, a cut to a reframed shot of the bodies with the observers visible on the hillside above them, and then a pan back across the length of the bodies. A remarkably composed shot from behind the soldier who has been visibly orchestrating much of the day's events captures the row of corpses through a salute, aligning the camera with a redemptive American gaze. A speech is made and wounded men, presumably former camp inmates, appear in reaction shots. Fuller again takes the opportunity to pan, this time to the left and from another position, from the observers to the bodies, to American soldiers, while also capturing the town behind them, a final reminder from the camp's interior of the complicity necessary for the camps to have existed. This chapter of the story comes to a close as the prepared bodies are carefully carried (by four men at a time) from the sheets to the back of a cart where they are re-stacked for transport to their final resting place.

Liberators were frequently confronted with such an overwhelming number of dead upon arrival at the camps that they were forced to bulldoze bodies into mass graves in an attempt to stave off disease. While the Falkenau ritual is far from that - the number of bodies is certainly incomparable with the numbers found at, say, Buchenwald or Belsen-there is a painful irony to the returning of these bodies to the piled state in which they were originally found, one that Fuller-who evinced a lifelong commitment to revealing the absurdity of war and its rituals - was likely aware of given the camera's articulate framing of this moment. Fuller, in fact, provides one shot of the corpse-filled cart that echoes our original glimpse of the bodies "thrown on top of each other like newspapers." One suspects that despite attempts at dignifying the dead, the point is that the lives lost are ultimately just that. Patriotism and a sense of moral certainty aside, Fuller was not above being realistic about the notion of liberation: "We were liberating them. But there was no way of saving them. Very few would survive. They were only free to die"
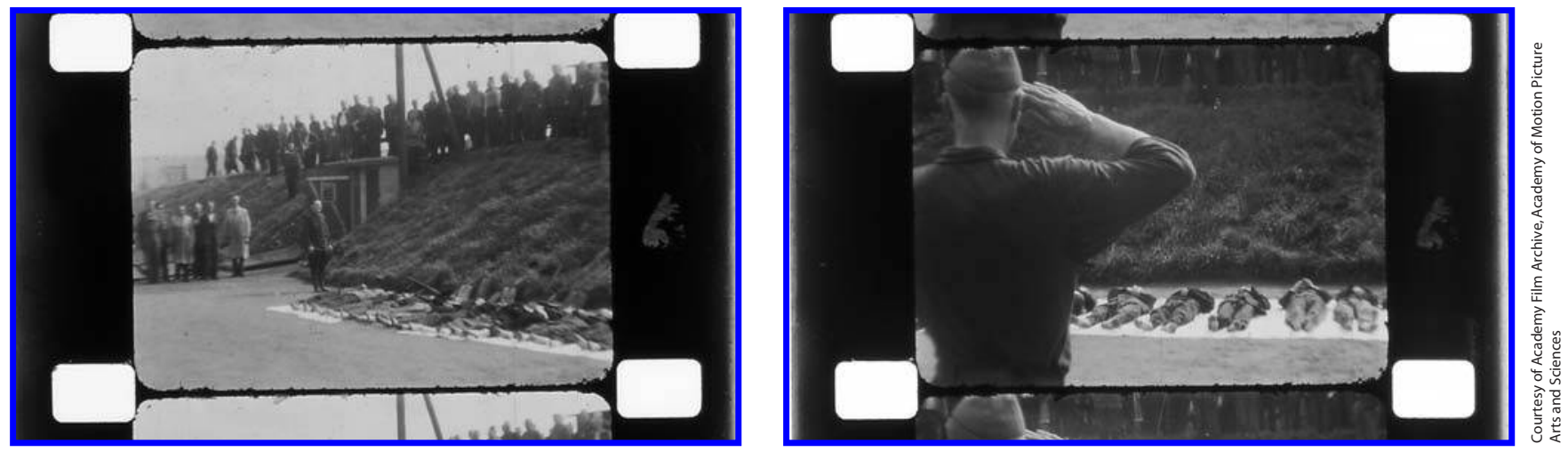

The camp with, mid-shot, its "putrid hut" and the patriotic image of a saluting soldier 
(215). The clothing, the observing, the burial all seek to restore dignity that is ultimately difficult, if not impossible, to confer. No amount of ceremony, the film seems to argue, can repair the irreparable. However, the film also suggests that this unusually careful ritual was a necessary drama for the survivors as well as for the liberators who intended, at minimum, to make motions towards civilized behavior and to force an apology, of sorts, from those who facilitated, either actively or passively, these conditions.

This first fourteen or so minutes of the film are thus dedicated to the preparation of the bodies for burial and they conclude with another shot of the "Good Show!" jeep leading the procession out of the camp and to the burial site. As an intertitle, the message seems irreverent. But it does speak to the theatrical, ceremonial aspects of what occurs. The next several minutes of the film take us into the town that we have been glimpsing outside of the camp's gates in what Fuller describes in Weiss's documentary as an act of intentional degradation, one that attests to Captain Richmond's desire to ratchet up the staging of this burial by creating a spectacle: the "leading VIP's of Falkenau" having "to pull and push these dead past the townspeople." The cart filled with the bodies is hauled-Richmond apparently "did not want any vehicle to transport the bodies ... they had to be pulled and pushed by the men who said, No one died in that camp atrociously" - through the town, accompanied by a tank and jeeps. ${ }^{29}$

At this parade-which recalls the processions that were central to the rise of the Third Reich, a kind of upending of the uniformed, mechanical mass spectacles that helped bring Hitler to power-Fuller captures yet another set of witnesses: other townspeople, including women and children, who had not been brought inside the camp's gates to aid in or witness the burial preparation, but who appear on the street to watch the convoy. The procession itself has grown larger, with at least one woman joining the ranks, and the marchers look intently at the camera as they pass it on their way to the gravesite. While the reactions of the town's onlookers are hard to read-many seem not to register much of anything in their expressions - an older male bystander to the right of the frame suddenly removes his hat. In Weiss's documentary Fuller explains that Captain Richmond told the man to take his hat off, presumably in a gesture of respect, again reminding us of the orchestration of the events depicted in Fuller's film. But, in another unusual moment, this time of surprising dissonance, Fuller captures a young German boy who has just shot his toy gun at the American convoy and who appears to be retrieving something (a discharged fake
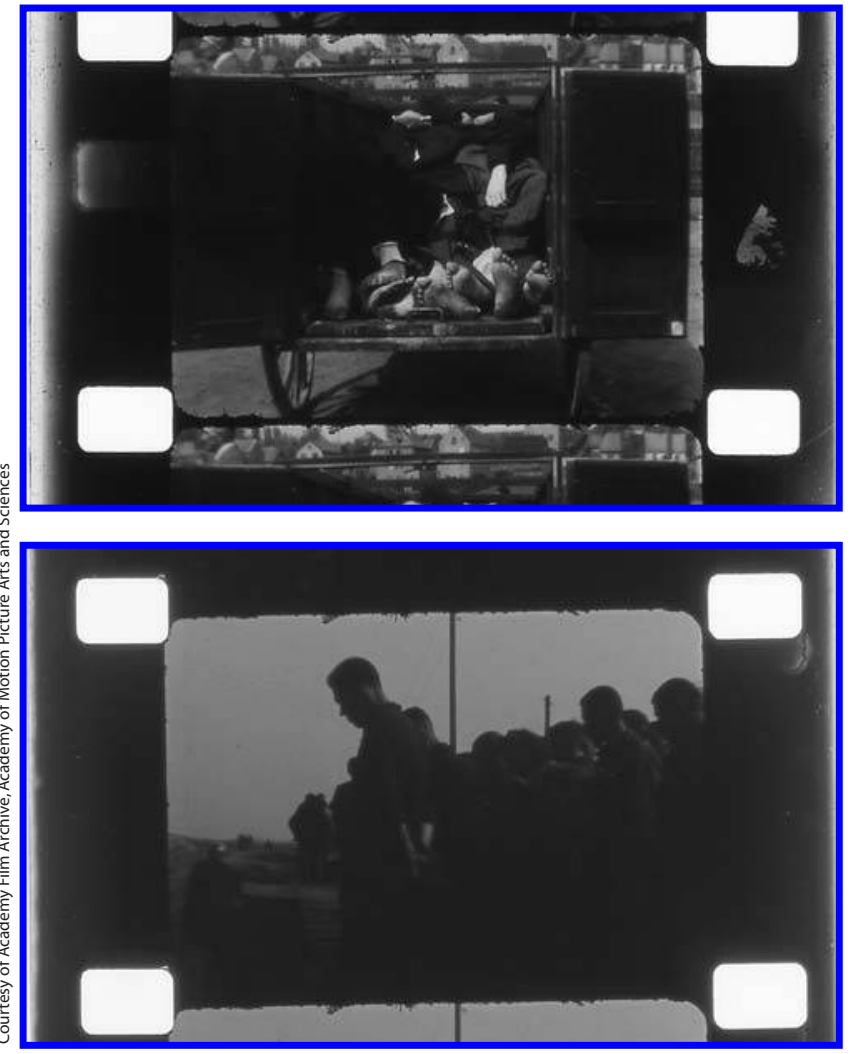

The dressed bodies stacked and onlookers at the mass gravesite

bullet?) from the street. The moment painfully indicates the degree to which those the spectatorial lesson was meant to reach could, even as that lesson made its way down their own streets, not see it in the way it was intended.

The concluding minutes of the Falkenau film depict the final internment of the bodies. Placed carefully in a mass grave, each man's arms are folded, jackets are adjusted, heads shifted. Fuller cuts between the grave and the bystanders, including a panning shot that rather poetically captures the shadows of the observers across one of the grave's walls. A German boy (perhaps in his early teens) is assigned the job of entering the pit to go across the line of bodies to ensure that arms and hands are correctly placed before he and a few others begin to drape white sheets over the top of the bodies. Fuller shoots the length of the grave and shows the camp survivors-several of them with "SU" (Soviet prisoners) printed on the back of their jackets-throwing a handful of dirt on top of the sheet-covered bodies. Then the shoveling of the rocky earth begins and Fuller provides a haunting shot of the sheet-covered bodies with dirt cascading onto them. There is one significant pause in the ritual, taken because one of the sheets has fallen off of the face of one of the bodies. A new sheet is 
procured, the head carefully covered, and dirt used to ensure that it will not slip away again. The film ends presumably as the ritual has. Burial is not just equated with closure; it is the end of this story, or at least of this part of the story.

Fuller's Falkenau footage is, as I have already noted, part of a genre of liberation films taken both by professional and amateur cinematographers for use as evidence of war crimes and, at least partly in Fuller's case, as a more personal memento of the war; this may not have been the original motivation for making the film (given Richmond's initiation of it), but it appears to have been the outcome up until the making of Weiss's documentary. Fuller's suppression of his own archived experiences - at least until he somewhat reluctantly unearthed them in an attempt to combat such Holocaust "minimizers," and therefore deniers, as France's JeanMarie Le Pen by participating in the making of the Weiss documentary-recalls what Griselda Pollock has termed the "eternal present" of trauma, ${ }^{30}$ which Fuller seems to have acknowledged by representing the Falkenau film as hidden away, "too painful to watch," never to be taken out again $(217,510-11)$. The fact that Fuller claimed to "still tremble to remember those images of the living hunkered down with the dead" (214) at Falkenau is striking both because of his desire to express a lingering visceral reaction that acknowledges the unfading power of those images and because what Fuller claims to remember here are images, not events and not the living and dead themselves.

This sense of mediation is crucial, reminding usas Dominick LaCapra does in History and Memory After Auschwitz - that "no memory is purely primary ... there is no fully immediate access to the experience itself even for the original witness." ${ }^{31}$ Although Fuller is not the only future filmmaker to have participated in the cinematic documentation of camp liberations, what Fuller depicts in his Falkenau footage and how he orders it is, based on the evidence I have encountered, unique. The meticulous care with which the individual bodies are prepared, clothed, displayed, and situated in the gravesite; the unhurried orchestration of the ritual from start to finish; and the formally meticulous presentation of it are all quite singular. Functioning as a witness, recorder, keeper of painful memories, and survivor in his own right, Fuller struggled with both the possession and the presentatation of this terrible subject matter. His treatment of the Falkenau footage attests to the traumatic burden that came with filming those who could not be saved, reinforcing the extent to which what happened in the camps continues to exceed adequate understanding, explanation, and visualiza- tion. Fuller's extraordinary rendering of this event and his fraught relationship with its existence recalls Janet Walker's observation that "the past is never wholly accessible, nor is it ever really over." 32 Fuller's remarkable footage, with its concern for the morality of witnessing and its humane effort to create a redemptive story out of the ruins of European culture, also reminds us that the visual evidence produced in and of Nazi Germany continues to unfurl, that the stories told by such truly moving images continue to surface like bits of repressed memory seeking expression.

\section{NOTES}

This article could not have been written without the help of Christa Lang Fuller, who allowed me to work with Sam Fuller's $16 \mathrm{~mm}$ films at the Academy of Motion Picture Arts and Sciences Academy Film Archive. I am also grateful to the Archive's director, Michael Pogorzelski and especially to archivist extraordinaire Snowden Becker for her uncommonly generous assistance in working with these materials both during my visit and after. Bruce Levy from the Steven Spielberg Film and Video Archive at the United States Holocaust Memorial Museum aided my navigation of that archive's moving-image collection of concentration camp liberations. Devin Orgeron and Frances Guerin expertly commented on drafts of this article. Finally, without the Orphan Film Symposium it is unlikely that I would have learned about AMPAS's Fuller holdings, or that I would have conceived of this area of research.

1. The quote is from Fuller's "An Essay on Film Directing Entithed 'Headlines to Headshots," in Tay Garnett, Directing: Leaning from the Masters (Lanham, MD: The Scarecrow Press, 1996), 90.

2. Falkenau (variants include "Falkenau an der Eger," "Falknov," and "Falkenow") was one of a hundred subcamps of Flossenbürg concentration camp. In Fuller's autobiography, A Third Face: My Tale of Writing, Fighting, and Filmmaking (New York: Alfred A. Knopf, 2002), he writes that the camp held "a tragic mix of Jews, Czechs, Poles, Russians, Gypsies, and antifascist Germans" (215-further quotations from this source are referenced parenthetically in the text of this article). In another context, Fuller claimed that Falkenau was "a camp for Russian soldiers, but many Americans were in it. They were mostly dying of TB. Dogtags had been removed, so we couldn't tell which corpses were Americans and which were not." Eric Sherman and Martin Rubin, The Director's Event (New York: Antheneum, 1970), 153. In Emil Weiss's documentary, Falkenau: The Impossible (1988), Fuller explains things differently: "we didn't know what country these prisoners were from. As far as we're concerned they could represent eight, ten, twelve different countries."

3. This footage along with Fuller's other $16 \mathrm{~mm}$ films from the war have been loaned by Fuller's widow, Christa Lang Fuller, at the AMPAS Film Archive. According to AMPAS archivist Snowden Becker, the Falkenau footage is approximately 650 feet and is edited-presumably by Fuller himself — onto a longer, approximately 1400-foot reel with other footage Fuller shot during the war.

4. Nicolas Losson, "Notes on the Images of the Camps," October 90 (1999): 25-35. 
5. See http://www.pbs.org/wgbh/pages/frontline/camp/ for more information.

6. Jeffrey Shandler, While America Watches: Televising the Holocaust (New York: Oxford University Press, 1999), 12. Photography also played a crucial role in Holocaust documentation. Carol Zemel, "Emblems of Atrocity: Holocaust Liberation Photographs," in Shelley Hornstein and Florence Jacobowitz, Image and Remembrance: Representation and the Holocaust (Bloomington: Indiana University Press, 2003), has documented the ways in which liberation photography established tropes that are quite similar to those of liberation films, including images of "German civilians summoned by Allied generals to view the camps and 'clean up' operationsprisoners or soldiers moving corpses from trains, wagons, pits" (206).

7. The third edition of Annette Insdorf's Indelible Shadows (New York: Cambridge University Press, 2003) provides the most in-depth treatment to date: two paragraphs that discuss the film in the context of Weiss's documentary.

8. Janet Walker, Trauma Cinema: Documenting Incest and the Holocaust (Berkeley: University of California Press, 2005), xviii. Walker is discussing a particular kind of contemporary documentary film of the past twenty years, but her engagement with issues of trauma, memory, and history are relevant here.

9. See Robert Abzug's Inside the Vicious Heart (New York: Oxford University Press, 1985) for more about the generals' visit and the sense of urgency in documenting the atrocities, especially 20-30 and 132-35. Abzug writes that "Eisenhower felt it was essential not only for his troops to see for themselves, but for the world to know about conditions at Ohrdruf and other camps. From Third Army headquarters he cabled London and Washington, urging delegations of officials and newsmen to be eye-witnesses to the camps" (20). All indications suggest that Fuller's footage was never used in any official capacity. The United States Holocaust Memorial Museum has a number of $8 \mathrm{~mm}$ and $16 \mathrm{~mm}$ films in their collection which were shot by amateur cinematographers following other camp liberations, including Mauthausen, Buchenwald, and Dachau.

10. Shandler, While America Watches, 6.

11. Ibid., 12.

12. Samuel Fuller, The Big Red One (New York: Bantam, 1980), unpaginated prefatory quote. The novel and the film are not strictly autobiographical, although many of the incidents that occur are repeated almost verbatim in A Third Face as autobiographical fact.

13. Fuller's explanation here is consistent with Janina Struk's conclusion about the fate of much of the photographic evidence taken by American soldiers, who were encouraged to photograph the atrocities they discovered at the camps but who often "kept their photographs hidden" instead of sharing them upon their return. Janina Struk, Photographing the Holocaust: Interpretations of the Evidence (London: I.B. Tauris, 2004), 31 .

14. As of the writing of this article Emil Weiss's French documentary, which includes excerpts of Fuller's $16 \mathrm{~mm}$ footage of Falkenau along with Fuller's narration of the film, and in which Fuller, according to Lee Server, Sam Fuller: Film Is a Battleground (Jefferson, NC: McFarland, 1994), returns "to the area of the camp" to discuss the footage, is not available in the United States. There appears to be only one print of the film in North America, on deposit at the AMPAS archive, and
Snowden Becker has generously provided me with a transcript of Fuller's narration of his Falkenau footage.

15. Margaret Bourke-White, Portrait of Myself (New York: Simon and Schuster, 1963), 259.

16. Snowden Becker carefully examined Fuller's original $16 \mathrm{~mm}$ film and detected around seventy splices, indicating a significantly edited film as opposed to one in which scenes were composed largely in-camera. Two different kinds of splices are evident in the film and it is possible that Fuller edited the film at different points in his life. Fuller shot the Falkenau footage on German-produced Gevaert safety stock but the opening titles are on Kodak film, suggesting that he likely shot the titles at a later date, perhaps after he returned to the United States. There are no date codes on either stock.

17. Note that Captain Richmond's first name is spelled differently here than it is in A Third Face.

18. In Weiss, Falkenau. Fuller states that there are twelve or fourteen of them, but I count sixteen to eighteen in this shot.

19. Losson, "Notes on the Images," 26.

20. Vivian Sobchack, "Inscribing Ethical Space: Ten Propositions on Death, Representation, and Documentary," Quarterly Review of Film Studies 9 (fall 1984): 283-300.

21. Ibid., 292.

22. Ibid., 291.

23. There look to be around fifty men in this shot. Later shots indicate a somewhat larger group, perhaps in the seventy-five to one hundred range.

24. Server, Sam Fuller, 22. In the Weiss documentary Fuller identifies the individuals handling the bodies very clearly as citizens of Falkenau: the gray-haired "very important banker" and other "leading VIP's."

25. Walker, Trauma Cinema, xxii.

26. Cornelia Brink, "Secular Icons: Looking at Photographs form Nazi Concentration Camps." History and Memory 12, no. 1 (spring-summer 2000): 142 .

27. Zemel, "Emblems of Atrocity," 206.

28. As Susan Caruthers argues in "Compulsory Viewing: Concentration Camp Film and German Re-education," Milennium 30, no. 3 (2001), panning and tracking shots also functioned "to place the provenance of the footage beyond question" (741) in official cinematic records of the camps.

29. In Weiss, Falkenau.

30. Griselda Pollock, "Holocaust Tourism: Being There, Looking Back and the Ethics of Spatial Memory," in David Crouch and Nina Lubbren (eds), Visual Culture and Tourism (New York: Berg, 2003), 176.

31. Dominick LaCapra, History and Memory After Auschwitz (Ithaca, NY: Cornell University Press, 1998), 21.

32. Walker, Trauma Cinema, 193.

MARSHA ORGERON is Assistant Professor of Film Studies at North Carolina State University.

ABSTRACT This article examines a neglected but important film from Samuel Fuller's formative years: the $16 \mathrm{~mm}$ footage he shot in 1945 , depicting a funeral ritual following his infantry division's liberation of Falkenau concentration camp. The footage provides a fascinating glimpse into the director's past and into World War II history.

KEYWORDS $16 \mathrm{~mm}$, concentration camps, war film, amateur film, World War II 